\title{
Physical, Mechanical and Thermal Behaviour of High Entropy Materials
}

\author{
Piyush Sharma ${ }^{1}$, Shashi Prakash Dwivedi ${ }^{*}$, Vijay Kumar Dwivedi ${ }^{1}$ \\ ${ }^{1}$ Department of Mechanical Engineering, IET, GLA University, Mathura, U.P. 281406, India \\ ${ }^{2}$ G. L. Bajaj Institute of Technology \& Management, Greater Noida, Gautam Buddha Nagar, U.P. 201310, India
}

Corresponding Author Email: shashi.dwivedi@glbitm.org

https://doi.org/10.18280/acsm.440208

Received: 5 Decemebr 2019

Accepted: 19 February 2020

\section{Keywords:}

corrosion behaviour, grain structure, hardness, high entropy alloy, tensile strength

\begin{abstract}
High-entropy alloys (HEAs) are alloys that are formed by mixing equal or relatively large proportions of (usually) five or more elements. Development of high entropy material is one of the biggest challenging areas in materials and design. However, high entropy materials exhibit very good mechanical properties. In the present investigation, an attempt was made to develop high entropy material by simple casting technique using $\mathrm{Cr}, \mathrm{Mn}, \mathrm{Fe}, \mathrm{Al}$ and $\mathrm{Ni}$ with equal weight percent. Squeeze pressure was applied on developed $\mathrm{Cr} 0.20 \mathrm{Mn} 0.20 \mathrm{Fe} 0.20 \mathrm{Al} 0.20 \mathrm{Ni} 0.20$ high entropy alloy to eliminate porosity and improve the grain structure. Microstructure image of Cr0.20Mn0.20Fe0.20A10.20Ni0.20 showed fair interfacial bonding between the alloys after squeeze pressure. Tensile strength, hardness was significantly improved of developed high entropy material. Physical and thermal behaviour such as corrosion loss and material sustainability were also observed to see the effect of different alloys interfacial reaction layer.
\end{abstract}

\section{INTRODUCTION}

In thermodynamics, entropy is commonly associated with the amount of order, disorder, or chaos in a thermodynamic system. This stems from Rudolf Clausius' 1862 assertion that any thermodynamic process always "admits to being reduced to the alteration in some way or another of the arrangement of the constituent parts of the working body" and that internal work associated with these alterations is quantified energetically by a measure of "entropy" change, according to the following differential expression. High entropy alloys (HEAs) are alloys comprises of five or more principal elements having atomic concentration range lies between 5-35 wt. \%. It consists of a single solid-solution having bodycentred cubic (BCC), face-centred cubic (FCC) or hexagonal close-packed (HCP) structure [1]. The HEAs attracts considerable interest in the field of intermetallic compounds due to their excellent mechanical, physical and thermal properties like tensile strength, hardness, ductility, density, corrosion and thermal expansion [2, 3]. It is well known that entropy of mixing of the $\mathrm{N}$ components randomly is given by;

$$
\mathrm{Smix}=-\mathrm{R} \sum \mathrm{Xi} \ln (\mathrm{Xi})
$$

where, $1 \leq \mathrm{I} \leq \mathrm{N}$

Here, $\mathrm{X}$ i represents the mole fraction of component $\mathrm{i}$ in the solution. The entropy of mixing of elements reaches the maximum value $\mathrm{R} \ln \mathrm{N}$ when the equal molar amount of each element is mixed. Therefore, alloys based on the value of $\mathrm{N}$ i.e number of alloying component classified in three categories namely: low entropy alloy having one principal metallic element, medium entropy alloy having two to four principal elements, High entropy alloy having at least five principal elements with equal/near-atomic concentration $[4,5]$. The concept of HEAs was first proposed by Yeh in 1995 in Taiwan. Cantor et.al in 2004 first investigate the alloy consisting of 20 elements in equal atomic proportions (i.e each having mole fraction of .05), and then also an alloy consisting of 16 components again in equal atomic proportion (i.e each having mole fraction of 0.0625 ). Both the alloys were found to be very brittle and comprise multiphase. The important characteristics of interested alloy are that it retains its mechanical properties at very high temperatures. These properties make it useful for various structural and high-temperature applications such as nuclear, aerospace industries and turbines [6].

Table 1. Some entropy alloys and their obtained properties

\begin{tabular}{|c|c|c|c|}
\hline $\begin{array}{l}\text { Ref. } \\
\text { No. }\end{array}$ & $\begin{array}{c}\text { Author's } \\
\text { Name }\end{array}$ & $\begin{array}{c}\text { Material } \\
\text { used }\end{array}$ & Result And conclusions \\
\hline$[1]$ & Guo et al. & $\begin{array}{l}\text { Iron, cobalt, } \\
\text { manganese, } \\
\text { nickel, } \\
\text { chromium. }\end{array}$ & $\begin{array}{l}\text { 1. As the carbon percentage } \\
\text { increases from } 0 \text { to } 0.1 \% \\
\text { the yield and ultimate } \\
\text { tensile strength of alloy } \\
\text { increases. } \\
2 \text {. The M23C6 carbide } \\
\text { precipitate in cold rolled } \\
\text { and HEA doped with } \\
\text { carbon, resist the motion of } \\
\text { grains boundaries thus } \\
\text { refines the size of grains. }\end{array}$ \\
\hline [2] & Gali et al. & $\begin{array}{l}\text { Iron, cobalt, } \\
\text { manganese, } \\
\text { nickel, } \\
\text { chromium. }\end{array}$ & $\begin{array}{l}\text { The tensile behaviour was } \\
\text { observed in the temperature } \\
\text { range }-196 \text { to } 1000 \text { Degree } \\
\text { Celsius and at strain rates of } \\
10^{-3} \text { to } 10^{-1} \text {. }\end{array}$ \\
\hline [3] & Deng et al. & $\begin{array}{l}\text { Iron, cobalt, } \\
\text { manganese, } \\
\text { nickel, } \\
\text { chromium. }\end{array}$ & $\begin{array}{l}\text { The mechanical properties } \\
\text { of Fe } 40 \mathrm{Mn} 40 \mathrm{CO} 10 \mathrm{Cr} 10 \\
\text { are better }\end{array}$ \\
\hline
\end{tabular}




\begin{tabular}{|c|c|c|c|}
\hline [4] & $\begin{array}{l}\text { Hemphill } \\
\text { et al. }\end{array}$ & $\begin{array}{l}\text { Aluminium, } \\
\text { Iron, cobalt, } \\
\text { manganese, } \\
\text { nickel, } \\
\text { chromium }\end{array}$ & $\begin{array}{l}\text { 1. The fatigue endurance } \\
\text { limit of the alloy was found } \\
\text { to be in between } 540 \text { to } 945 \\
\text { Mpa. } \\
\text { 2. The fatigue endurance } \\
\text { limit to ultimate tensile } \\
\text { strength ratio found to be in } \\
\text { between } 0.402 \text { and } 0.703 \text {. }\end{array}$ \\
\hline [5] & $\begin{array}{l}\text { Karlsdottir } \\
\text { et al. }\end{array}$ & $\begin{array}{l}\text { Aluminium, } \\
\text { Iron, } \\
\text { manganese, } \\
\text { nickel, } \\
\text { chromium }\end{array}$ & $\begin{array}{l}\text { The alloy } \mathrm{AlFeMnNiCr} \text { is } \\
\text { not suitable for geothermal } \\
\text { steam rich in } \mathrm{H} 2 \mathrm{~S} \text { and } \mathrm{CO}_{2}\end{array}$ \\
\hline [6] & $\begin{array}{l}\text { Cortie et } \\
\text { al. }\end{array}$ & $\begin{array}{l}\text { Copper, Iron, } \\
\text { manganese, } \\
\text { nickel, } \\
\text { chromium, } \\
\text { aluminium, } \\
\text { vanadium, } \\
\text { titanium }\end{array}$ & $\begin{array}{l}\text { A new parameter } \Phi \text {, the } \\
\text { ratio between Gibbs free } \\
\text { energy of disordered solid } \\
\text { solution to the segregated } \\
\text { binary system is defined. } \\
\text { Formation of HEA's is } \\
\text { favoured when the value of } \\
\Phi>1 \text {. }\end{array}$ \\
\hline [7] & $\begin{array}{l}\text { Won-Mi- } \\
\text { Choi et al. }\end{array}$ & $\begin{array}{l}\text { Iron, cobalt, } \\
\text { manganese, } \\
\text { nickel, } \\
\text { chromium. }\end{array}$ & $\begin{array}{l}\text { 1. It is concluded that room } \\
\text { temperature and cryogenic } \\
\text { HPT processing of } \\
\text { CoCrFeMnNi alloy } \\
\text { affected its microstructure } \\
\text { and mechanical properties. } \\
\text { 2. The result showed that } \\
\text { grain refinement was } \\
\text { hindered by FCC to HCP } \\
\text { phase transformation. }\end{array}$ \\
\hline [8] & Otto et al. & $\begin{array}{l}\text { Iron, cobalt, } \\
\text { manganese, } \\
\text { nickel, } \\
\text { chromium. }\end{array}$ & $\begin{array}{l}\text { 1. The yield strength of } \\
\text { alloy increased as the grain } \\
\text { size decreased from } 155 \text { to } \\
4.4 \mu \mathrm{m} \text { up to the } \\
\text { temperature range of } 873 \mathrm{~K} \text {. } \\
\text { 2. The alloy shows a strong } \\
\text { increase in yield and } \\
\text { ultimate tensile strength } \\
\text { when the temperature } \\
\text { decreases. The elongation } \\
\text { up to fracture also increased } \\
\text { with decreasing } \\
\text { temperatures. }\end{array}$ \\
\hline [9] & $\begin{array}{l}\text { Schuh et } \\
\text { al. }\end{array}$ & $\begin{array}{l}\text { Iron, cobalt, } \\
\text { manganese, } \\
\text { nickel, } \\
\text { chromium. }\end{array}$ & $\begin{array}{l}\text { 1. Isochronal heat } \\
\text { treatments for } 1 \text { hour to a } \\
\text { significant hardening at a } \\
\text { temperature up to } 450^{\circ} \mathrm{C} \\
\text { before softening set in for } \\
\text { high annealing } \\
\text { temperature. } \\
\text { 2. Isothermal heat treatment } \\
\text { at hardening temperature of } \\
450^{\circ} \mathrm{C} \text { result sufficient } \\
\text { increase of hardness up to } \\
\text { approximately } 100 \text { hours. } \\
\text { Nanocrystalline }\end{array}$ \\
\hline [10] & $\begin{array}{l}\text { Vaidya et } \\
\text { al. }\end{array}$ & $\begin{array}{l}\text { Iron, cobalt, } \\
\text { manganese, } \\
\text { nickel, } \\
\text { chromium. }\end{array}$ & $\begin{array}{l}\text { FeCrMnNiCo having stable } \\
\text { FCC structure. Cobalt and } \\
\text { Manganese having the } \\
\text { slowest dissolution kinetics } \\
\text { during mechanical alloying }\end{array}$ \\
\hline [11] & $\begin{array}{l}\text { Wang et } \\
\text { al. }\end{array}$ & $\begin{array}{l}\text { Iron, cobalt, } \\
\text { Aluminium, } \\
\text { nickel, } \\
\text { chromium }\end{array}$ & $\begin{array}{l}\text { A high entropy material } \\
\text { was produced with a BCC } \\
\text { crystal structure. The } \\
\text { microstructure is polygonal } \\
\text { grains having dendrite } \\
\text { segregation area. }\end{array}$ \\
\hline [12] & Lee et al. & $\begin{array}{l}\text { Iron, cobalt, } \\
\text { manganese, } \\
\text { nickel, }\end{array}$ & $\begin{array}{l}\text { The addition of } \mathrm{Mn} \text { to } \\
\text { AlFeCrCoMnNi alloy } \\
\text { increases the hardness, }\end{array}$ \\
\hline
\end{tabular}

\begin{tabular}{|c|c|c|c|}
\hline & & $\begin{array}{l}\text { chromium, } \\
\text { aluminium. }\end{array}$ & $\begin{array}{l}\text { yield stress, ultimate tensile } \\
\text { strength. }\end{array}$ \\
\hline [13] & $\begin{array}{l}\text { Zhong et } \\
\text { al. }\end{array}$ & $\begin{array}{l}\text { Iron, cobalt, } \\
\text { manganese, } \\
\text { nickel, } \\
\text { chromium, } \\
\text { aluminium, } \\
\text { copper. }\end{array}$ & $\begin{array}{l}\text { HEA prepared by laser } \\
\text { cladding have a } \\
\text { homogeneous composition } \\
\text { and have a crystalline size } \\
\text { of approximately 10nm. } \\
\text { The addition of aluminium } \\
\text { promotes the transition of } \\
\text { FCC to BCC } \\
\text { microstructure. }\end{array}$ \\
\hline [14] & $\begin{array}{l}\text { Zhang et } \\
\text { al. }\end{array}$ & $\begin{array}{l}\text { Iron, cobalt, } \\
\text { manganese, } \\
\text { nickel, } \\
\text { chromium, } \\
\text { copper. }\end{array}$ & $\begin{array}{l}\text { The stability of the phase is } \\
\text { determined by Gibbs free } \\
\text { energy change. The equal } \\
\text { atomic composition of } \\
\text { elements leads to high } \\
\text { entropy of mixing. }\end{array}$ \\
\hline [15] & Lee et al. & $\begin{array}{l}\text { Iron, } \\
\text { manganese, } \\
\text { nickel, } \\
\text { chromium, } \\
\text { aluminium }\end{array}$ & $\begin{array}{l}\text { The aluminium free alloy } \\
\text { has more resistant to } \\
\text { corrosion than that of } \\
\text { aluminium-containing } \\
\text { alloy in an acidic } \\
\text { environment. }\end{array}$ \\
\hline [16] & $\begin{array}{l}\text { Wang et } \\
\text { al. }\end{array}$ & $\begin{array}{l}\text { Iron, cobalt, } \\
\text { aluminium, } \\
\text { nickel, } \\
\text { chromium. }\end{array}$ & $\begin{array}{l}\text { Low aluminium content } \\
\text { alloys result in FCC } \\
\text { Structure and as the Al } \\
\text { content increases it induces } \\
\text { the formation of BCC } \\
\text { phase. }\end{array}$ \\
\hline [17] & $\begin{array}{l}\text { Elkatatny } \\
\text { et al. }\end{array}$ & $\begin{array}{l}\text { Iron, } \\
\text { manganese, } \\
\text { aluminium, } \\
\text { nickel, } \\
\text { chromium }\end{array}$ & $\begin{array}{l}\text { The A110 alloy has low } \\
\text { cost, FCC structure, } \\
\text { excellent cold workability, } \\
\text { and better mechanical } \\
\text { properties than that of Al5 } \\
\text { alloy. The Al10 Alloy } \\
\text { exhibit significantly higher } \\
\text { strain hardening rates and } \\
\text { lower deformation } \\
\text { twinning mechanism than } \\
\text { that of Al5 alloy. }\end{array}$ \\
\hline [18] & He et al. & $\begin{array}{l}\text { Iron, cobalt, } \\
\text { manganese, } \\
\text { nickel, } \\
\text { chromium, } \\
\text { aluminium. }\end{array}$ & $\begin{array}{l}\text { The aluminium-containing } \\
\text { alloy was divide into three } \\
\text { regimes: Al concentration } \\
\text { below } 8 \% \text { result in single- } \\
\text { phase FCC when Al } \\
\text { concentration lies between } \\
8 \% \text { and } 16 \% \text { result in FCC } \\
+ \text { BCC phase, and BCC } \\
\text { solid solution after } 16 \% \text {. }\end{array}$ \\
\hline [19] & Fang et al. & $\begin{array}{l}\text { Iron, cobalt, } \\
\text { manganese, } \\
\text { nickel, } \\
\text { chromium. }\end{array}$ & $\begin{array}{l}\text { The HEAs having HCP } \\
\text { microstructure has higher } \\
\text { elastic modulus compared } \\
\text { to FCC. HEAs indicate that } \\
\text { addition of the HCP phase } \\
\text { determines the hardening of } \\
\text { dual-phase high entropy } \\
\text { alloy. }\end{array}$ \\
\hline
\end{tabular}

As the aluminium content increases in the alloy, there are progressive increases in the hardness of the alloy due to a single ordered BCC solid solution phase [20, 21]. Some entropy alloys and their obtained properties are discussed in Table 1 .

From the archival literature, it can be observed that most of the researchers developed the high entropy alloy by using elements such as Iron, cobalt, manganese, nickel, chromium, aluminium etc. Most of the researchers identified the mechanical behaviour of high entropy alloys (HEAs). In the present study, high entropy alloy was developed using $\mathrm{Cr}, \mathrm{Mn}$, $\mathrm{Fe}, \mathrm{Al}$ and $\mathrm{Ni}$ elements with equal weight proportions. There 
microstructure image, tensile strength, hardness and corrosion behaviour was observed to identify the influence of elements in the development of the HEAs

\section{MATERIALS AND METHODS}

\subsection{Development of high entropy alloy}

The HEA was produced through by simple casting technique. Element $\mathrm{Cr}, \mathrm{Mn}, \mathrm{Fe}, \mathrm{Al}$ and $\mathrm{Ni}$ with the purity of more than $99 \%$ were selected with equal weight percent $(20$ wt. \% each). All the elements in the ingot form were melted in the different furnace. Melted elements were poured into the common graphite crucible with different time and temperature. Mixed HEA was allowed to cool in the graphite crucible. High entropy alloy was also transferred to the UTM machine for squeeze pressure to eliminate the porosity and refined the grain structure. Figure 1 shows the line diagram UTM machine used for squeeze pressure using punching die. Table 1 shows the randomly selected composition of high entropy alloys.

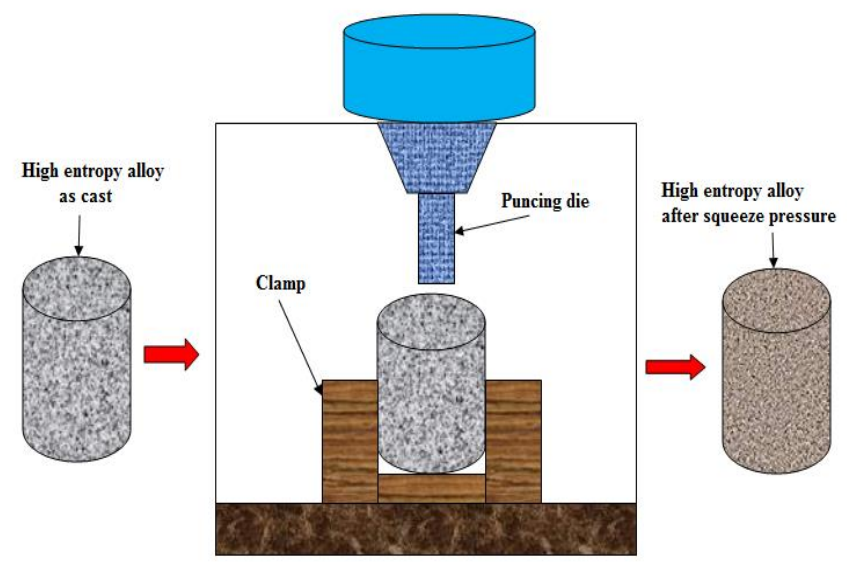

Figure 1. UTM machine used for squeeze pressure using punching die

\subsection{Mechanical characterizations and sample preparation}

The developed composites were characterized in terms of microstructure, tensile strength, hardness $(10 \mathrm{~mm} \times 10 \mathrm{~mm} \times$ $25 \mathrm{~mm}$ ), thermal expansion and corrosion loss of HEA alloys. The tensile sample was prepared on a lathe machine. The tensile samples were tested at room temperature. Tensile samples were prepared according to ASTM B557 standard (Test methods for tension testing wrought and cast aluminium and magnesium-alloy products). The diameter of the sample prepared was $6 \mathrm{~mm}$ and the gauge length was $36 \mathrm{~mm}$. The tensile test was conducted on the tensometer. Hardness test was performed on the Brinell Hardness Testing Machine.

\section{RESULT AND DISCUSSION}

\subsection{Microstructure analysis of HEA}

Microstructures of Cr0.20Mn0.20Fe0.20Al0.20Ni0.20 high entropy alloy are shown in Figure 2 (a) and Figure 2 (b) of ascast and after squeeze pressure respectively. It has been observed that the grain structure of high entropy alloy was more refined after applying the squeeze pressure in the mushy zone. When five different alloys were mixed, then there were some difficulties occurred during the solidification of elements due to different solidification temperature. Resulting, porosity and cracks are developed inside the high entropy alloy. Porosity, cracks are removed by applying the squeeze pressure on HEA.
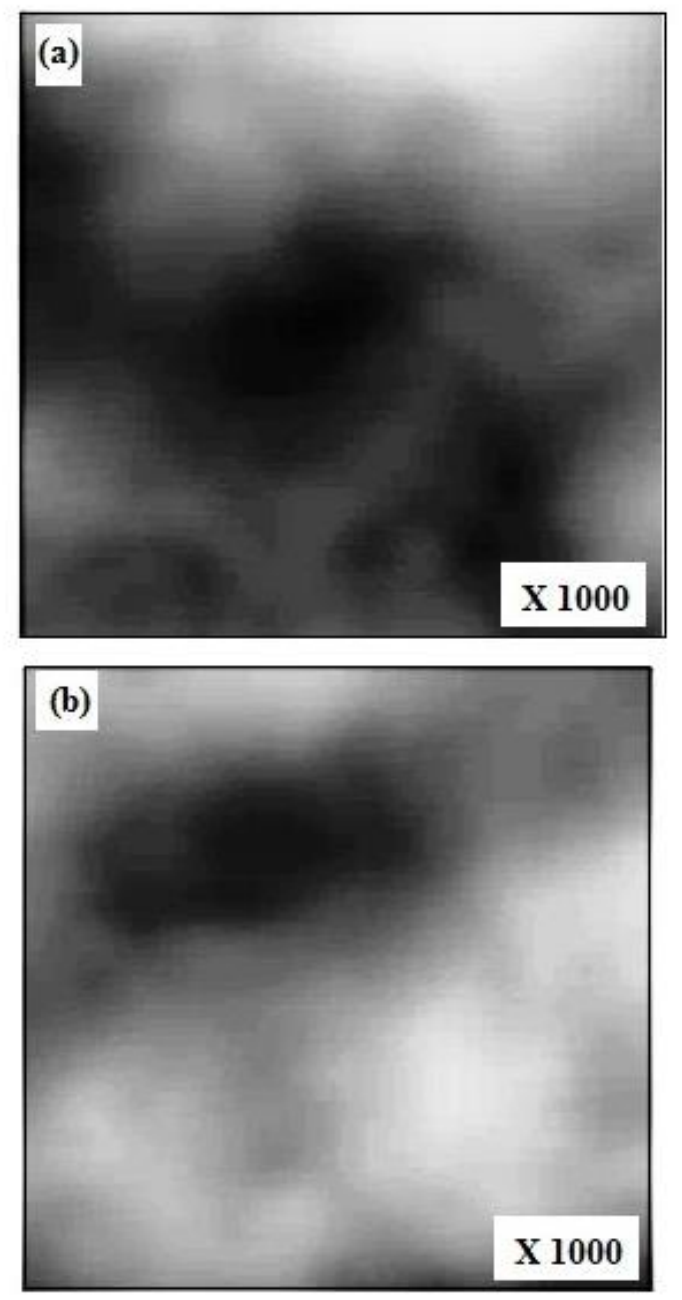

Figure 2. Microstructure image of

Cr0.20Mn0.20Fe0.20A10.20Ni0.20 high entropy alloy; (a) as-cast and (b) after squeeze pressure

Figure 2 (a) shows the microstructure image of $\mathrm{Cr} 0.20 \mathrm{Mn} 0.20 \mathrm{Fe} 0.20 \mathrm{Al} 0.20 \mathrm{Ni} 0.20 \mathrm{high}$ entropy alloy as-cast. Some agglomeration of elements can be observed. Figure 2 (b) shows the microstructure image of Cr0.20Mn0.20Fe0.20A10.20Ni0.20 high entropy alloy after squeeze pressure. Fair grain structure and proper bending between the elements can be observed.

Figure 3 shows the SEM images of Cr0.20Mn0.20Fe0.20A10.20Ni0.20 high entropy alloy. Some porosity can be observed during the development of high entropy alloy. Figure 4 shows the SEM images of Cr0.20Mn0.20Fe0.20A10.20Ni0.20 high entropy alloy after the squeeze pressure applied in the mushy zone. The fine-grain structure has been obtained after applying the squeeze pressure in the mushy zone. Fine-grain structure enhanced the tensile strength as well as the hardness of high entropy alloy. The fine grain structure of the developed high entropy alloy also enhanced the bonding between the elements. 


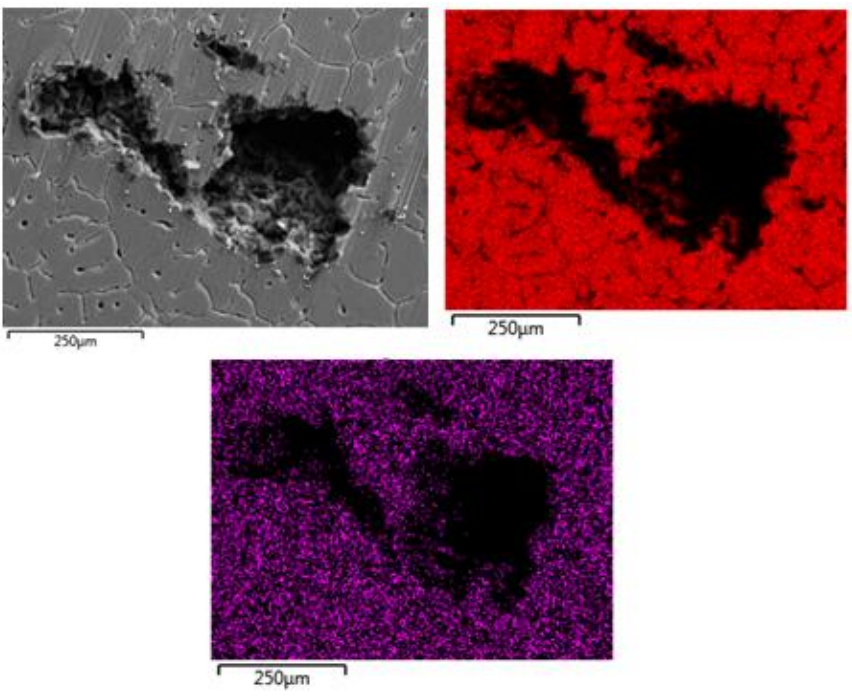

Figure 3. SEM images of $\mathrm{Cr} 0.20 \mathrm{Mn} 0.20 \mathrm{Fe} 0.20 \mathrm{~A} 10.20 \mathrm{Ni} 0.20$ high entropy alloy showing porosity
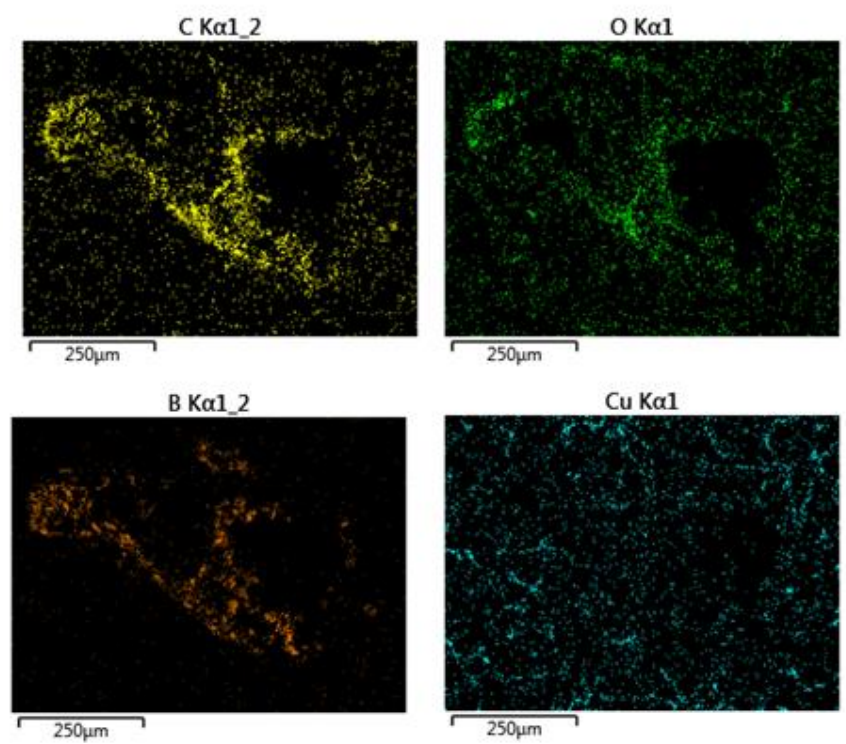

Figure 4. SEM images of Cr0.20Mn0.20Fe0.20A10.20Ni0.20 high entropy alloy after squeeze pressure

\subsection{Tensile strength analysis}

Comparative Tensile Strength analysis of Cr0.20Mn0.20Fe0.20Al0.20Ni0.20 high entropy alloy with individual elements is shown in Figure 5. Tensile strength analysis graph was plotted with 5\% deviation bars. Tensile strength of pure aluminium was found to be $130 \mathrm{MPa}$. Tensile strength of Mn was observed $475 \mathrm{MPa}$. Tensile strength of high entropy alloy was found to be $360 \mathrm{MPa}$. It can be observed that about $176.92 \%$ tensile strength improved concerning aluminium. However, tensile strength decreased by about $24.21 \%$ concerning $\mathrm{Mn}$. Tensile strength of Cr0.20Mn0.20Fe0.20Al0.20Ni0.20 high entropy alloy was further improved after applying the squeeze pressure.

Tensile strength of HEA after squeeze pressure was found to be $395 \mathrm{MPa}$. Results showed that tensile strength has been significantly improved after applying the squeeze pressure on HEA.

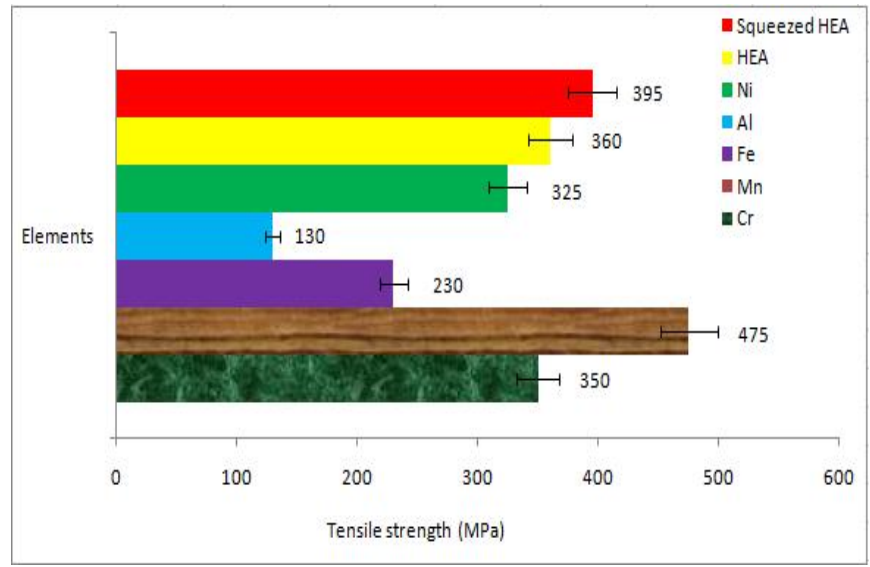

Figure 5. Comparative tensile strength analysis of Cr0.20Mn0.20Fe0.20Al0.20Ni0.20 high entropy alloy with individual elements

\subsection{Hardness}

The hardness of $\mathrm{Cr} 0.20 \mathrm{Mn} 0.20 \mathrm{Fe} 0.20 \mathrm{Al} 0.20 \mathrm{Ni0} .20$ high entropy alloy was observed and compared with the hardness of individual elements as shown in Figure 6. The hardness of HEA was also significantly improved with respect to individual elements $(\mathrm{Cr}, \mathrm{Fe}, \mathrm{Al}, \mathrm{Ni})$. The hardness of HEA improved about $2.60 \%, 55.19 \%, 177.56 \%$ and $11.025 \%$ with respect to the hardness of $\mathrm{Cr}, \mathrm{Fe}, \mathrm{Al}$ and $\mathrm{Ni}$ respectively. The hardness of HEA further improved after applying the squeeze pressure. Fair grain structure and proper bonding between the elements are responsible for enhancing the hardness of Cr0.20Mn0.20Fe0.20Al0.20Ni0.20 high entropy alloy.

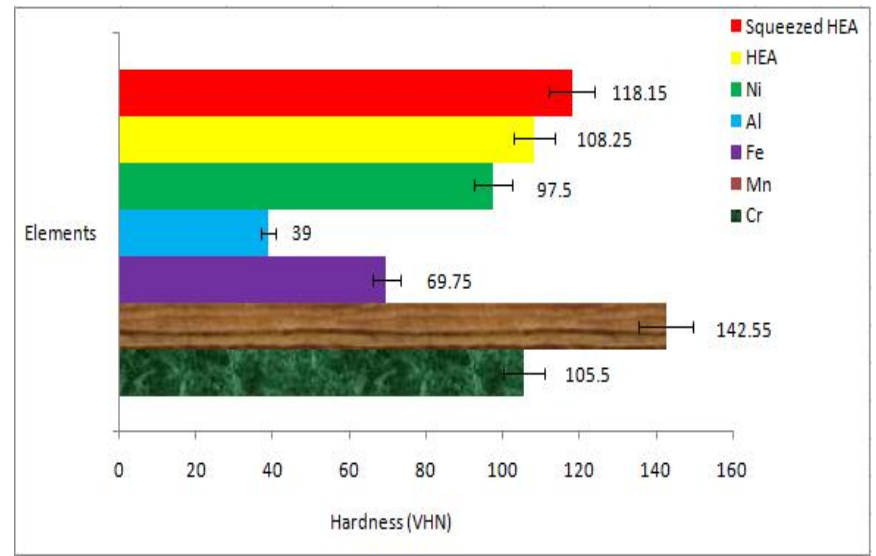

Figure 6. Comparative hardness analysis of Cr0.20Mn0.20Fe0.20Al0.20Ni0.20 high entropy alloy with individual elements

\subsection{Corrosion resistance}

Corrosion behaviour of each sample was performed in 3.5 wt. $\% \mathrm{NaCl}$ for 120 hours. Weight of each sample was kept 9 gm before performing the corrosion test. Maximum weight loss was found to be $0.215 \mathrm{gm}$ for $\mathrm{Fe}$ after corrosion test. However, weight loss for $\mathrm{Cr} 0.20 \mathrm{Mn} 0.20 \mathrm{Fe} 0.20 \mathrm{Al} 0.20 \mathrm{Ni} 0.20$ high entropy alloy was found to be $0.016 \mathrm{gm}$. These results showed that developed HEA has good corrosive resistance in an acetic acid environment. 


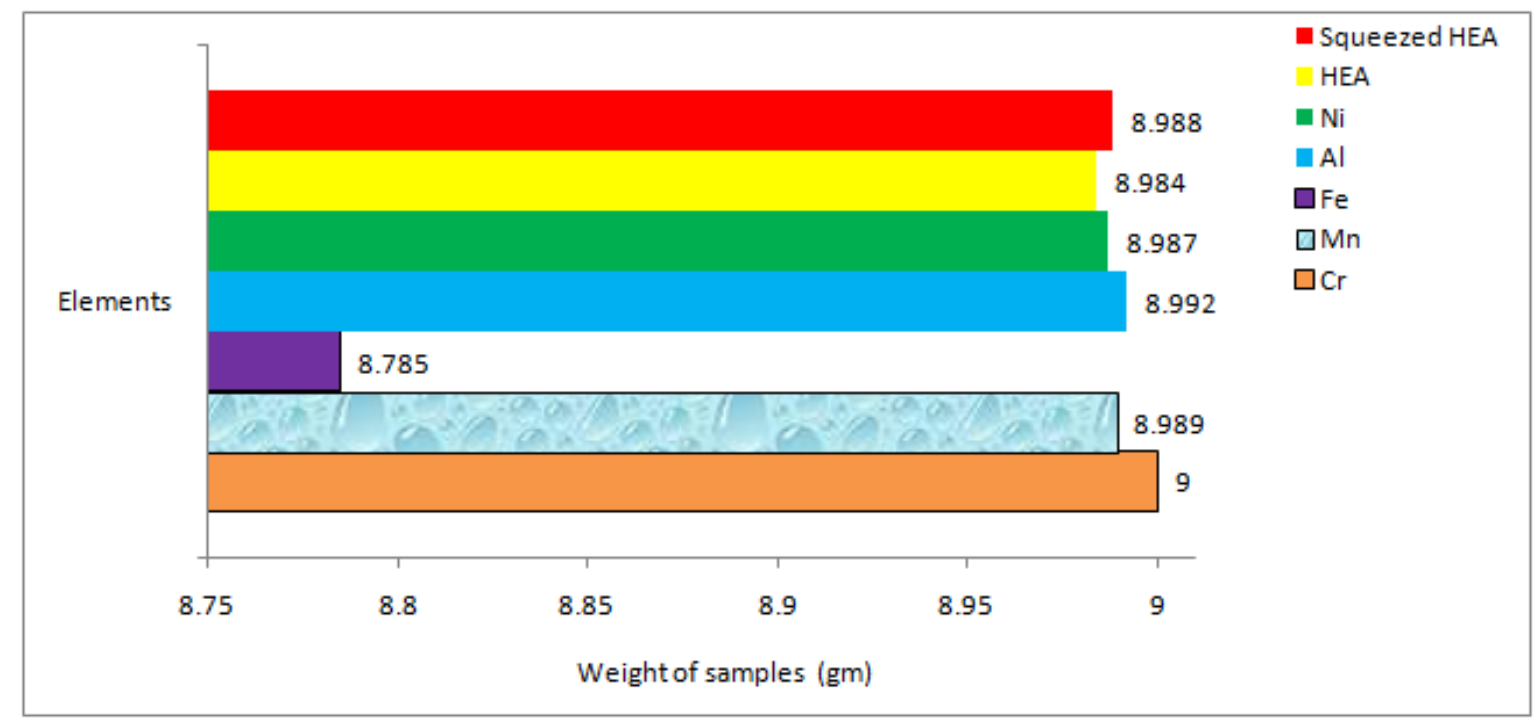

Figure 7. Comparative corrosion weight loss behaviour of $\mathrm{Cr} 0.20 \mathrm{Mn} 0.20 \mathrm{Fe} 0.20 \mathrm{Al} 0.20 \mathrm{Ni} 0.20$ high entropy alloy with individual elements

The corrosion resistance of the materials was further improved after applying the squeeze pressure as shown in Figure 7. Weight loss of the HEA after squeeze pressure was found to be $0.012 \mathrm{gm}$.

\subsection{Thermal expansion behaviour of HEA}

Thermal expansion behaviour of HEA was observed at $450^{\circ} \mathrm{C}$ for 24 hours. Sometimes, material sustainability in the high-temperature environment has to require as per the need of the application. The volume of each sample was kept 2500 $\mathrm{mm}^{3}$ before the test. Thermal expansion behaviour of HEA alloy (Cr0.20Mn0.20Fe0.20Al0.20Ni0.20 high entropy alloy) before and after extrusion was identified.

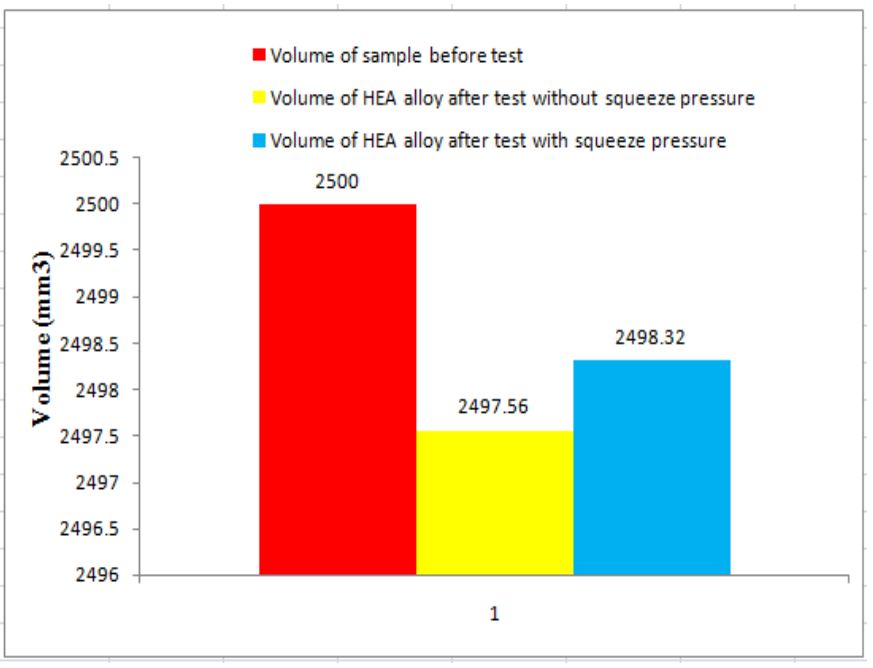

Figure 8. Thermal expansion behaviour of Cr0.20Mn0.20Fe0.20Al0.20Ni0.20 high entropy alloy with and without squeeze pressure

Figure 8 shows the comparative study of thermal expansion behaviour of HEA alloy before and after the squeeze pressure. The volume of the HEA alloy with and without squeeze pressure after the thermal expansion was found to be 2498.32 $\mathrm{mm}^{3}$ and $2497.56 \mathrm{~mm}^{3}$ respectively. Results showed that after the squeeze pressure, material sustainability improved significantly in a high-temperature environment.

\section{CONCLUSIONS}

Conclusive points from the present study are given below:

1. High entropy alloy with equal weight percent of $\mathrm{Cr}, \mathrm{Mn}$, $\mathrm{Fe}, \mathrm{Al}$ and $\mathrm{Ni}$ can be developed using simple casting technique.

2. The microstructure of Cr0.20Mn0.20Fe0.20Al0.20Ni0.20 high entropy alloy after squeeze pressure showed better grain structure and less porosity.

3. Tensile strength and hardness of Cr0.20Mn0.20Fe0.20Al0.20Ni0.20 high entropy alloy significantly improved after applying the squeeze pressure.

4. Weight loss of the Cr0.20Mn0.20Fe0.20Al0.20Ni0.20 high entropy alloy is lower than Iron. While strength is much better than Iron.

5. Thermal expansion results showed that material sustainability of high-temperature alloy after squeeze pressure enhanced significantly.

6. In this study weight percent of each element $(\mathrm{Cr}, \mathrm{Mn}$, $\mathrm{Fe}, \mathrm{Al}, \mathrm{Ni}$ ) have been considered uniform (20\%). It has been recommended for the future work that properties of high entropy alloy can be observed by varying weight percent of the composition.

7. It has been recommended for the future work that behaviour such as martensite, austenite, and ferrite of Cr0.20Mn0.20Fe0.20Al0.20Ni0.20 high entropy alloy can be observed.

\section{REFERENCES}

[1] Guo, L., Ou, X.Q., Ni, S., Liu, Y., Yong, L., Song, M. (2019). Effects of carbon on the microstructures and mechanical properties of FeCoCrNiMn high entropy alloys. Material Science and Engineering A, 746: 356362. https://doi.org/10.1016/j.msea.2019.01.050 
[2] Gali, A., George, E.P. (2015). Tensile properties of highand medium-entropy alloys. Intermetallics, 39: 74-78. https://doi.org/10.1016/j.intermet.2013.03.018

[3] Deng, Y., Tasan, C.C., Pradeep, K.G., Springer, H., Kostka, A., Raabe, D. (2015). Design of a twinninginduced plasticity high entropy alloy. Acta Materialia, 94: 124-133. https://doi.org/10.1016/j.actamat.2015.04.014

[4] Hemphill, M.A., Yuan, T., Wang, G.Y., Yeh, J.W., Tsai, C.W., Chuang, A., Liaw, P.K. (2012). Fatigue behavior of $\mathrm{Al}_{0.5} \mathrm{CoCrCuFeNi}$ high entropy alloys. Acta Materialia, 60(16): https://doi.org/10.1016/j.actamat.2012.06.046

[5] Karlsdottir, S.N., Csaki, I., Antoniac, I.V., Manea, C.A., Stefanoiu, R., Magnus, F., Miculescu, F. (2019). Corrosion behavior of AlCrFeNiMn high entropy alloy in a geothermalm environment. Geothermics, 81: 32-38. https://doi.org/10.1016/j.geothermics.2019.04.006

[6] King, D.J.M., Middleburgh, S.C., McGregor, A.G. (2016). Predicting the formation and stability of single phase high-entropy alloys. Acta Materialia, 104: 172-179. https://doi.org/10.1016/j.actamat.2015.11.040

[7] Moon, J., Qi, Y., Tabachnikova, E., Estrin, Y., Choi, W.M., Joo, S.H., Lee, B.J., Podolskiy, A., Tikhonovsky, M., Kim, H.S. (2018). Microstructure and mechanical properties of high-entropy alloy Co20Cr26Fe20Mn20Ni14 processed by high-pressure torsion at $77 \mathrm{~K}$ and 300K. Scientific Reports, 8: 11074. https://doi.org/10.1038/s41598-018-29446-y

[8] Otto, F., Dlouhy, A., Somsen, C., Bei, H., George, E.P. (2013). The influences of temperature and microstructure on the tensile properties of a CoCrFeMnNi high-entropy alloy. Acta Materialia, 61: 5743-5755. https://doi.org/10.1016/j.actamat.2013.06.018

[9] Schuh, B., Martin, F.M., Völke, B., George, E.P., Clemens, H. (2015). Mechanical properties, microstructure and thermal stability of a nanocrystalline $\mathrm{CoCrFeMnNi}$ high-entropy alloy after severe plastic deformation. Acta Materialia, 96: 258-268. https://doi.org/10.1016/j.actamat.2015.06.025

[10] Vaidya, M., Karati, A., Marshal, A., Pradeep, K.G., Murty, B.S. (2019). Phase evolution and stability of nanocrystalline $\mathrm{CoCrFeNi}$ and $\mathrm{CoCrFeMnNi}$ high entropy alloys. Journal of Alloys and Compounds, 770: 1004-1015. https://doi.org/10.1016/j.jallcom.2018.08.200

[11] Wang, Y.P., Li, B.S., Ren, M.X., Yang, C., Fu., H.Z. (2008). Microstructure and compressive properties of $\mathrm{AlCrFeCoNi}$ high entropy alloy. Material Science and Engineering A, 491: 154-158. https://doi.org/10.1016/j.msea.2008.01.064

[12] Wong, S.K., Shun, T.T., Chang, C.H., Lee, C.F. (2018).
Microstructures and properties of Al0.3CoCrFeNiMnx high-entropy Alloys. Materials Chemistry and Physics, 210:

146-151. https://doi.org/10.1016/j.matchemphys.2017.07.085

[13] Ye, X.Y., Ma, M.X., Liu, W.J., Li, L., Zhong, M.L., Liu, Y.X., Wu, Q.W. (2011). Synthesis and Characterization of High-Entropy Alloy AlXFeCoNiCuCr by Laser Cladding. Advance in Material Science and Engineering, 5. https://doi.org/10.1155/2011/485942

[14] Zhang, F., Zhang, C., Che, S.L., Cao, W.S., Zhu, J., Kattner, U.R. (2014). An understanding of high entropy alloys from phase diagram calculations. Calphad, 45: 110. https://doi.org/10.1016/j.calphad.2013.10.006

[15] Lee, C.P., Chang, C.C., Yeh, J.W. Chen, Y.Y., Shih, H.C. (2008). Effect of the aluminium content of $\mathrm{Al}_{\mathrm{x}} \mathrm{CrFe}_{1.5} \mathrm{MnNi}_{0.5}$ high-entropy alloys on the corrosion behaviour in aqueous environments. Corrosion Science, 50(7): 2053-2060. https://doi.org/10.1016/j.corsci.2008.04.011

[16] Wang, W.R., Wang, W.L., Wang, S.C., Tsai, Y.C., Lai, C.H., Yeh, J.W. (2012). Effects of Al addition on the microstructure and mechanical property of AlxCoCrFeNi high-entropy alloys. Intermetallics, 26: 44-51. https://doi.org/10.1016/j.intermet.2012.03.005

[17] Elkatatny, S., Gepreel, M.A.H., Hamada, A., Nakamura, K., Yamanaka, K., Chiba, A. (2019). Effect of Al content and cold rolling on the microstructure and mechanical properties of $\mathrm{Al}$ Cr12Fe35Mn28Ni20 high-entropy alloy. Material Science and Engineering, 759: 380-390. https://doi.org/10.1016/j.msea.2019.05.056

[18] He, J.Y., Liu, W.H., Wang, H., Wu, Y., Lu, Z.P. (2014). Effects of $\mathrm{Al}$ addition on structural evolution and tensile properties of the FeCoNiCrMn high-entropy alloy system. Acta Materialia, 62: 105-113. https://doi.org/10.1016/j.actamat.2013.09.037

[19] Fang, Q.H., Chen, Y., Li, J., Jiang, C., Liu, B., Liu, Y., Liaw, P.K. (2018). Probing the phase transformation and dislocation evolution in dual-phase high entropy alloys. International Journal of Plasticity, 114: 161-173. https://doi.org/10.1016/j.ijplas.2018.10.014

[20] Dwivedi S., Sharma S., Mishra R. (2016). Mechanical and metallurgical characterizations of AA2014/Eggshells waste particulate metal matrix composite. International Journal of Precision Engineering and Manufacturing-green Technology, 3: 281-288. https://doi.org/10.1007/s40684-016-0036-0

[21] Dwivedi, S., Sharma, S., Mishra, R. (2016). Synthesis and mechanical behaviour of green metal matrix composites using waste eggshells as reinforcement material. Green Process Synth, 5(3): 275-282. https://doi.org/10.1515/gps-2016-0006 